\title{
免震改修した通天閣の
}

\section{8 年大阪府北部の地震の地震応答シミュレーション解析}

\author{
宮本裕司 ${ }^{1)}$ ，佐藤綾香 ${ }^{2)}$ \\ 1) 正会員 大阪大学大学院工学研究科, 教授 博士 (工学) \\ e-mail : miyamoto@arch.eng.osaka-u.ac.jp \\ 2) 大阪大学大学院工学研究科, 大学院生 \\ e-mail : sato_ayaka@arch.eng.osaka-u.ac.jp
}

\begin{abstract}
要 約
1956年に竣工した大阪の通天閣は，2015年に免震改修が行われた．本研究では，免震改修 前後の通天閣の振動性状と地震応答性状を把握するため，常時微動測定と地震観測を行っ た．地震観測では，改修前に2013年淡路島の地震，改修後の2018年に大阪府北部の地震の 記録が地下階と屋上階で観測された。これらの地震記録を用いたシミュレーション解析を 行い，改修前後の通天閣の応答性状を分析するとともに免震改修の効果を確認した.
\end{abstract}

キーワード： 鉄骨造タワー，免震改修，振動計測，地震観測，シミュレーション解析

\section{1. はじめに}

内藤多仲によって設計され 1956 年に竣工した 2 代目通天閣は，大阪のシンボルとして年間 130 万人 が訪れる有名な鉄骨造のタワーであり, 竣工後 50 年が経過した 2006 年に登録有形文化財に指定された. その間の 1994 年には，塔脚部から 3 階までの改修および鉄骨塗装と展望室改修といった平成の大改修 が行われた ${ }^{1)}$. 通天閣が建つ大阪府では，南海卜ラフ巨大地震や上町断層帯地震の発生が懸念されてい る ${ }^{2)}$. そのため, 大地震時の通天閣の被害をできる限り軽減することを目的に, 2015 年に 4 本の脚部に 免震装置を取り付けた免震改修が行われた ${ }^{3), 4)}$. 写真 1 に免震改修した通天閣を示寸.

通天閣の振動計測は, 竣工後の 1956 年に内藤ら 5)によって行われた. その 14 年後の 1970 年には那須 ら のにより振動計測が行われ，その振動性状と経年による変化が無いことが報告された，その後，平成

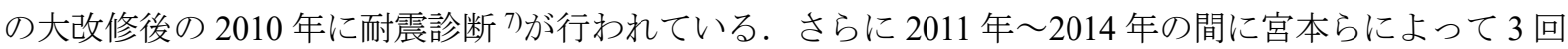
の詳細な振動計測 ${ }^{8)}$, 9)が行われ, 免震改修前の通天閣の固有周期, 減衰定数, 振動モード等が把握され た. 2012 年には地下階と展望室から屋上階に出る階段の踊り場の 2 カ所に地震計を設置し, 地震観測が 行なわれている。

本論文では, 免震改修前の 2013 年 4 月 13 日に観測された淡路島の地震と, 免震改修後の 2018 年 6 月 18 日に観測された大阪府北部の地震の記録を対象に分析およびシミュレーション解析を行い, 改修前後 の通天閣の地震時の応答性状と免震効果について分析した. 




写真 1 通天閣

\section{表 1 通天閣の概要}

\begin{tabular}{lll}
\hline 所在地 & \multicolumn{2}{l}{ 大阪市浪速区恵美寿東 } \\
設計者 & 内藤多仲 & \\
設計年 & 1955 年(S30) \\
竣工年 & 1956 年(S31) \\
階数 & 地上 & 6 階 \\
& 地下 & 1 階 \\
高さ & 最高高さ & $108 \mathrm{~m}$ \\
& 塔体高さ & $100 \mathrm{~m}$ \\
構造種別 & 地上部 & $\mathrm{S}$ 造, SRC 造 \\
& & $(1 \sim 3$ 階 RC 被覆) \\
& & 免震構造 \\
& & $\mathrm{RC}$ 造 \\
& 地下部 & 独立基礎 \\
基礎構造 & 直接基䃈 \\
& & 布基礎 \\
用途 & 展望塔 & \\
\hline
\end{tabular}

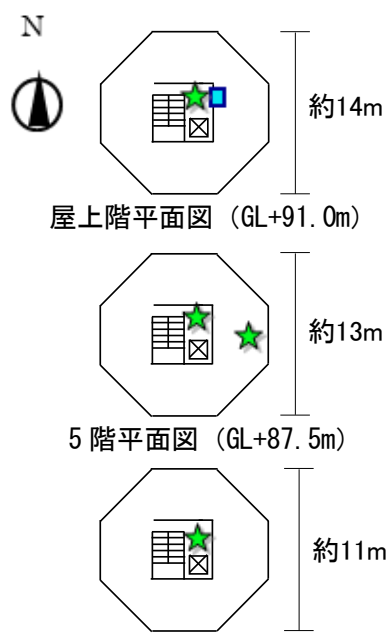

4 階平面図 $(\mathrm{GL}+84.0 \mathrm{~m})$

図 2 各階の測定位置

図 1 建物概要と第 4 回振動計測時の測定点位置

\section{2. 通天閣の概要}

通天閣は表1に示寸ように，地上6階地下1階，高さ約 $100 \mathrm{~m} （$ 避雷針までの高さは $108 \mathrm{~m} ）$ の展望塔であ る. 建物は図 1 に示すように，平面形状がおおよそ $24 \mathrm{~m} \times 24 \mathrm{~m}$ の鉄塔部分と，その東側にある直径約 $5.5 \mathrm{~m}$ の円筒状のエレベーター（E.V）塔，およびそれらをつなぐ渡り廊下により構成されている.

主塔の中央部には，エレベーターシャフトと屋内階段を有する．地上 $26 \mathrm{~m}$ 部分（3階屋上）までは正方 形平面，地上 $26 \mathrm{~m}$ 以上は八角形平面となっており，地上部は鉄骨造のトラス構造である，ただし，地上 $26 \mathrm{~m}$ の階屋上までは, 柱, 梁, 斜材を鉄筋コンクリートで被覆している ${ }^{1} .2015$ 年の免震改修では, 地 上 $18 \mathrm{~m}$ の3階床レベルをエレベーター塔と切り離してエクスパンションジョイントとし, 地上 $9.5 \mathrm{~m}$ 位置で 4本の脚部を切断して免震装置を設け, 脚部を鉄筋コンクリートで補強された.

地下室は鉄筋コンクリート造の耐震壁付きラーメン構造であり, GL-5.58mの深さで直接基礎で支持さ れている. 


\section{3. 免震改修前の通天閣の振動性状}

通天閣の振動計測は過去に 5 回行われた. 既往文献による第 1 回, 第 2 回の計測結果 5), 6) と併せて, 著者らによる振動計測で得られた固有周期と減衰定数をまとめて表 2 に示す。これらの結果から，主塔 の $\mathrm{NS}$ 方向と $\mathrm{EW}$ 方向の 1 次固有周期は 1.56 秒付近で変化は小さく, 建設直後からの振動性状の経年変 化はほとんど認められない.

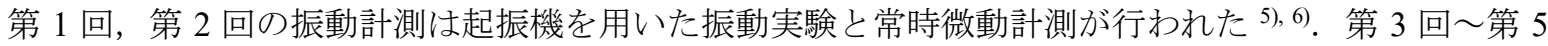
回では常時微動計測と人力加振を行った ${ }^{8), 9)}$. 図 1 に第 4 回計測時の測定点位置を示寸. 微動計は, 図 1 に示寸々印の位置に設置し，5 階では図 2 に示寸ように，階段室内だけでなく，東側の床上でも計測を 行いねじれ振動を計測した。人力加振実験は，第 3 回〜第 5 回の計測時に，4階で NS，EW 方向それぞ れの 1 次固有周期に合わせて加振を行い，計測は 5 階東側の床上で行った．減衰定数は人力加振波形の 安定した減衰域（図 3 の網掛け部分）で最小二乗法を用いて算定した。図 3 に，計測波形の例として第 3 回計測時の 5 階床東側での波形を示寸. 表 2 に示したように減衰定数は $0.70 \sim 0.99 \%$ とやや幅がある結

表 2 微動計測による固有周期と減衰定数のまとめ

\begin{tabular}{|c|c|c|c|c|c|c|c|c|}
\hline \multirow{3}{*}{$\begin{array}{c}\text { 固有周期 } \\
\text { (s) }\end{array}$} & \multicolumn{7}{|c|}{ 主塔 } & \multirow{3}{*}{$\begin{array}{c}\text { E.V 塔 } \\
\text { NS 方向 } \\
1 \text { 次 }\end{array}$} \\
\hline & \multicolumn{3}{|c|}{ NS 方向 } & ねじれ & \multicolumn{3}{|c|}{ EW 方向 } & \\
\hline & 1 次 & 2 次 & 3 次 & 1 次 & 1 次 & 2 次 & 3 次 & \\
\hline $\begin{array}{c}\text { 第 } 1 \text { 回 } \\
\text { (1956 年) }\end{array}$ & 1.56 & 0.37 & 0.3 & - & 1.54 & 0.37 & 0.3 & - \\
\hline $\begin{array}{c}\text { 第 } 2 \text { 回 } \\
\text { (1970 年) }\end{array}$ & 1.59 & 0.41 & 0.33 & - & 1.59 & 0.4 & 0.31 & \\
\hline $\begin{array}{c}\text { 第 } 3 \text { 回 } \\
\text { (2011 年) }\end{array}$ & 1.56 & 0.43 & 0.31 & $\begin{array}{c}0.64 \\
(0.74)\end{array}$ & $\begin{array}{c}1.56 \\
(0.85)\end{array}$ & 0.42 & 0.32 & 0.34 \\
\hline $\begin{array}{c}\text { 第 } 4 \text { 回 } \\
\text { (2013 年) }\end{array}$ & $\begin{array}{c}1.56 \\
(0.99)\end{array}$ & 0.41 & 0.3 & 0.64 & $\begin{array}{c}1.55 \\
(0.71)\end{array}$ & 0.4 & 0.32 & 0.34 \\
\hline $\begin{array}{c}\text { 第 } 5 \text { 回 } \\
\text { (2014 年) }\end{array}$ & $\begin{array}{l}1.55 \\
(0.7)\end{array}$ & 0.41 & 0.31 & 0.65 & $\begin{array}{l}1.55 \\
(0.7)\end{array}$ & 0.4 & 0.31 & 0.35 \\
\hline
\end{tabular}

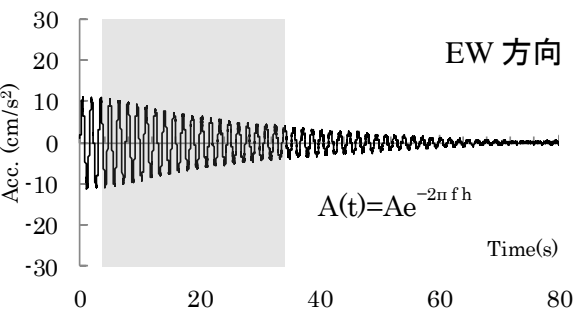

図 3 人力加振後の自由振動波形 $\left(T_{1}=1.56 \mathrm{~s}\right.$ 第 3 回計測時)

※（）内は減衰定数（\%)を表す
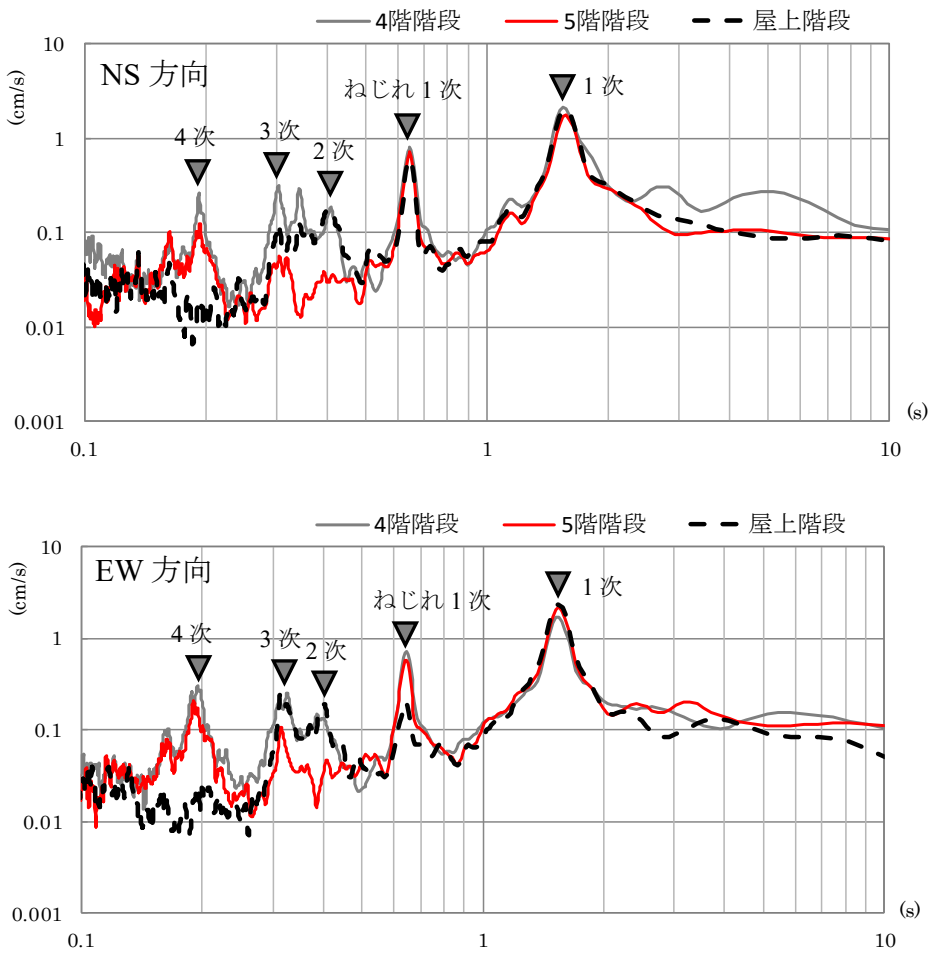

図 4 フーリエスペクトル（展望階周辺） 
果であった．特に第 4 回計測時の NS 方向の值が大きいのは，計測時に風が強く，安定した自由振動波 形が計測されなかったことによる.

第 4 回計測時の結果として, 屋上階・5 階・4 階の階段室内で得られた常時微動波形のフーリエスペク トルを図 4 に示す. NS, EW 両方向ともす心゙ての階で， 1 次固有周期 1.56 秒と㸚じれ 1 次固有周期 0.64 秒での卓越が見られる. 2 次, 3 次のモードに関しては, 明瞭に卓越している屋上階と 4 階に比べ, その 間にある 5 階では振幅が小さい．また，4 次モードでは屋上階以外の階で振幅が大きくなり，高次の振 動モードでは節となる高さによって各階の振幅が異なる.

第 5 回の常時微動計測では, 屋上階, 4 階のほかに, 新たに塔屋上, 屋上階, 地上 $75 \mathrm{~m}, 59 \mathrm{~m}, 43 \mathrm{~m}$ 高 さ, 3 階屋上および 2 階でも計測を行った. これらの結果から求めた主塔 $\mathrm{EW}$ 方向の 1 次〜3 次モード を図 5 に示寸．なお，振幅は各固有周期でフーリエ振幅を用い，展望階を基準とした伝達関数から各計 測点の位相差を変化させて描いた。これより，5 階の展望階で， 2 次， 3 次モードの節となっていること がわかる。

\section{4. 通天閣の免震改修}

通天閣の免震改修工事の概要について示す. 有形文化財である通天閣の外観を変えないよう, GL+9.5m 高さの脚部に免震構造が採用された ${ }^{3)}$, 4). 図 6 に免震層の概要を示寸. 架構の安定化を図るため, 免震 層の上下は強固なコンクリート基礎および補強鉄骨梁で補強された，免震装置には，表 3 に示寸天然ゴ

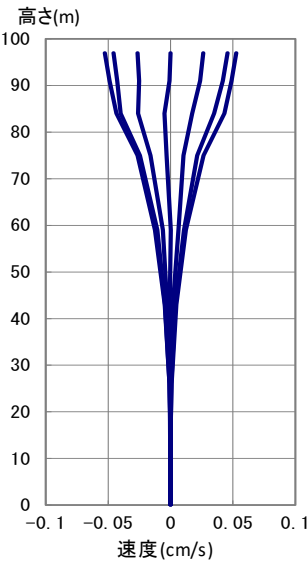

(a) 1 次モード

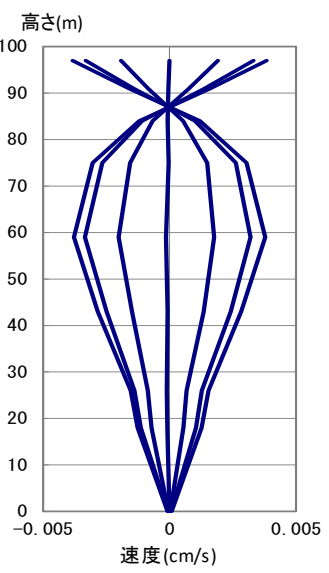

(b) 2 次モード

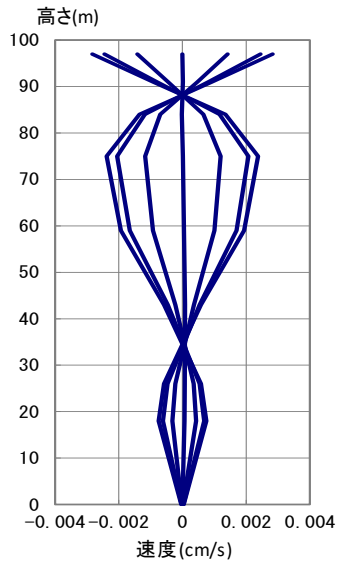

(c) 3 次モード

図 5 振動計測から求めた振動モード図(EW 方向)

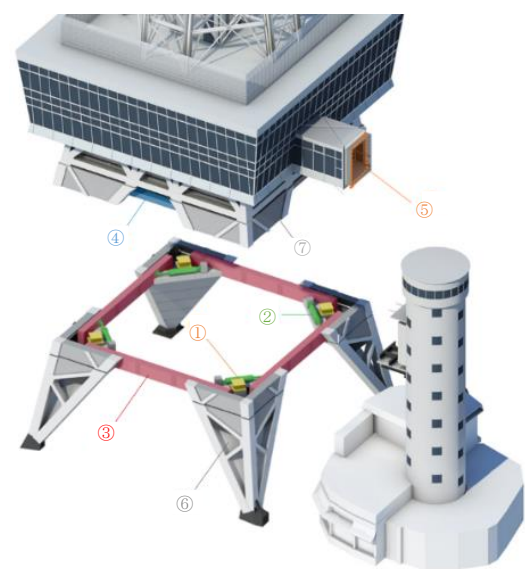

(1) 天然ゴム系積層ゴム支承

(2) ロック機構付速度比例型オイルダンパー

(3) コンプレッションガーダ

(4) テンションガーダ

(5) 蛇腹 Exp.

(6) 補強コンクリート(下部)

(7) 補強コンクリート(上部)

図 6 免震改修の概要 ${ }^{3), 4)}$ 
ム系積層ゴム $\square-900 \mathrm{~mm}$ （ゴム層厚 $197.2 \mathrm{~mm}$ ，高さ $451.1 \mathrm{~mm}$ ） と速度比例型のオイルダンパー(最大減衰 力 $1,000 \mathrm{kN}$, 減衰係数 $1,000 \mathrm{kN} \cdot \mathrm{s} / \mathrm{m}$ )が採用された. 強風時における居住性向上のための手段として, オ イルダンパーには電磁ロック機構を有したロック機構付速度比例型オイルダンパーが採用された. 電磁 ロックは建物管理者による解除が可能となっており，地震あるいは強風後の残留変位に対しても，ロッ クを解除することで積層ゴムの復元力により原位置に復元できる ${ }^{3)}$. エレベーター塔と繋ぐ渡り廊下部 分は，免震層の大きな変位に追従するため鉄道連結部に用いられる蛇腹で繋がれている.

免震改修での耐震設計クライテリアは，レベル2地震動に対しても既存鉄骨部材に生じる応力が短期 許容応力度以下であり, レベル2地震動に対する免震層変位の目標值は $540 \mathrm{~mm}$ 以下とし, $460 \mathrm{~mm}$ に抑え られている，渡り廊下の蛇腹は，変位 $-400 〜+750 \mathrm{~mm}$ に対して損傷が生じないことが確認されている。

\section{5. 免震改修前後の通天閣の地震応答解析モデル}

図 7(a)に改修前モデルを示す. 主塔のモデル化は, 立体フレームモデルをもとに地上部を 25 質点の曲 げせん断型モデルで，1 階柱脚を固定とした。なお，常時微動計測の固有周期と合うように展望階付近 の初期岡性を調整した。 また，エレベーター塔は 8 質点の等価せん断型モデルに置換し，固有周期 0.34 秒に合うようモデル化した。 このように作成した主塔とエレベーター塔を，渡り廊下の 2 方向の剛性の 違いをモデル化した一本のばねで結び，2 塔連成のモデルを作成した.

図 7(b)に改修後モデルを示す. 免震層上部の 23 質点 は, 改修前と同様の曲げせん断型モデルを用い た. 免震層下部の脚部は, 改修後の立体モデルをもとに等価な剛性をもつ 4 本の脚部からなるラーメン

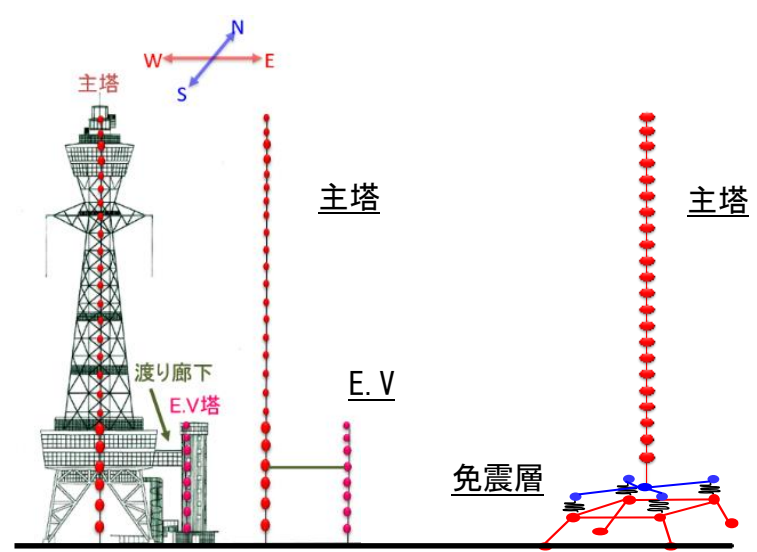

（a）改修前 (b) 改修後

図 7 地震応答解析モデル

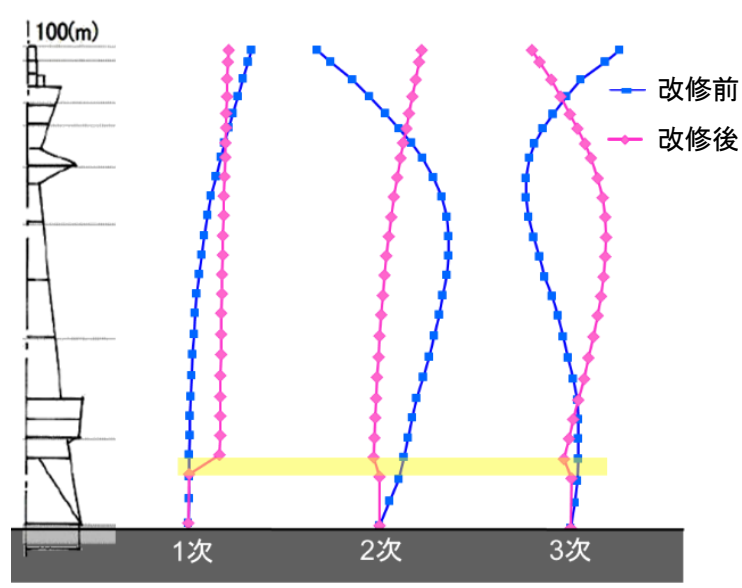

図 9 改修前後の固有モードの比較 (EW 方向)
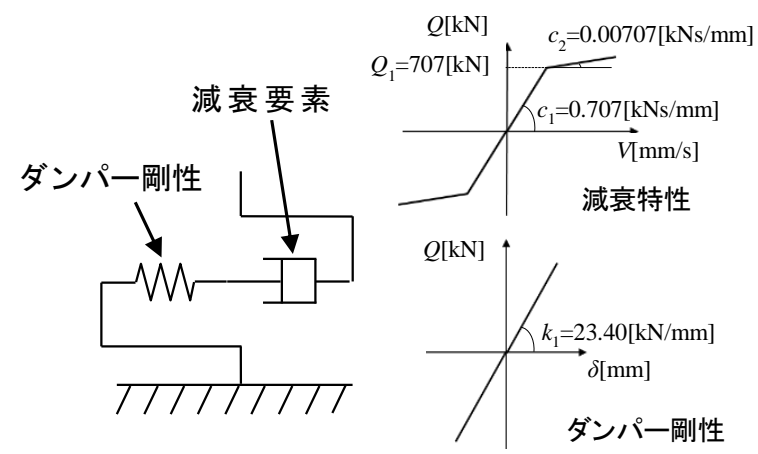

(a) 模式図

（b）復元力特性

図 8 オイルダンパーのモデル化

表 3 積層ゴムとダンパーの水平方向特性 (1 基分)

\begin{tabular}{|c|c|c|c|c|}
\hline \multirow{2}{*}{ 積層ゴム } & \multicolumn{4}{|c|}{ ダンパー } \\
\cline { 2 - 5 } & ダンパー岡性 & \multicolumn{3}{|c|}{ 減衰特性 } \\
\hline $\begin{array}{c}k_{0} \\
(\mathrm{kN} / \mathrm{mm})\end{array}$ & $\begin{array}{c}k_{1} \\
(\mathrm{kN} / \mathrm{mm})\end{array}$ & $\begin{array}{c}c_{1} \\
(\mathrm{kNs} / \mathrm{mm})\end{array}$ & $\begin{array}{c}c_{2} \\
(\mathrm{kNs} / \mathrm{mm})\end{array}$ & $\begin{array}{c}Q_{1} \\
(\mathrm{kN})\end{array}$ \\
\hline \hline 3.08 & 23.40 & 0.707 & 0.00707 & 707 \\
\hline
\end{tabular}

表 4 改修前後の固有値の比較(固有周期(s))

\begin{tabular}{|c|c||c|c|c|}
\hline 方向 & & 1 次 & 2 次 & 3 次 \\
\hline \multirow{2}{*}{$\mathrm{NS}$} & 改修前 & 1.56 & 0.41 & 0.25 \\
\cline { 1 - 5 } & 改修後 & 4.73 & 1.46 & 0.33 \\
\hline \multirow{2}{*}{$\mathrm{EW}$} & 改修前 & 1.56 & 0.41 & 0.25 \\
\cline { 1 - 5 } & 改修後 & 4.73 & 1.46 & 0.32 \\
\hline
\end{tabular}


構造にモデル化した. 改修前に比べ, 改修後モデルは下層部で重量が大きく, 建物全体で 1.53 倍となる. また，改修後のモデルは，主塔とエレベーター塔の間にエクスパンションジョイントを設けるため主塔 のみとした．免震層には，4 基の積層ゴムとオイルダンパーを並列に配置した.オイルダンパーは，図 8(a)に示すようにダンパー剛性と減衰要素を直列に接続し, 配置方向に合わせて $45^{\circ}$ 方向に変換した. モ デルでは図 8(b)に示寸線形逆行型の応力-速度関係をもつダッシュポットと, 線形の応力-変形関係をも つばねにモデル化した，天然ゴム系積層ゴムは，メーカー仕様のばね值をもつ線形ばね $\left(k_{0}=3.08 \mathrm{kN} / \mathrm{mm}\right)$ とした.

改修前後の上記の振動モデルから求めた主塔の固有值解析結果を, 表 4 に示寸. 1 次固有周期は, 両 方向とも改修前 1.56 秒に比べ改修後 4.73 秒となり, 免震装置による長周期化が確認できる. 改修前後 の EW 方向の 1〜3 次までの固有モードを図 9 に示寸．それぞれのモード形が比較しやすいように適宜 振幅を調整し，重ね描いている。これより，免震改修を施すことで， 1 次と 2 次の振動モードでは免震 層上部の架構の層間変位が小さくなること，3 次の振動モードは展望階付近がモードの節となることが 確認できる.

\section{2013年淡路島の地震のシミュレーション解析（改修前）}

図 7(a)に示した多質点曲げせん断型モデルを用いて，改修前の観測地震のシミュレーション解析を行 った結果を以下に示す.

\section{1 観測地震と地震記録}

2013 年 4 月 13 日 5 時 33 分頃, 淡路島を震源とするマグニチュード 6.3 , 震源深さ約 $15 \mathrm{~km}$ の地震が 発生した. 地震のタイプは, 逆断層型の内陸地殼内地震で, 最大震度は 6 弱（兵庫県淡路市）であった. 地震の概要を表 5 に示寸 ${ }^{10}$ ). 地震による通天閣位置（大阪市浪速区）の震度は 3 であり，通天閣の屋上 階と地下階に設置した地震計（図 1 参照）で，図 10 と図 11 に示寸加速度波形が観測された。屋上階の 波形を見ると，時間軸で 20〜 40 秒の主要動付近では短周期成分の波形が目立つが， 60 秒付近からの後

表 5 観測地震の概要 ${ }^{10)}$

\begin{tabular}{|c||c|}
\hline 発生日時 & 2013 年 4 月 13 日午前 5 時 33 分頃 \\
\hline 震央 & 兵庫県淡路島付近 (北緯 34.4 度, 東経 134.8 度) \\
\hline 震源深さ & 約 $15 \mathrm{~km}$ \\
\hline マグニチュード & 6.3 \\
\hline 最大震度 & 6 弱 $($ 兵庫県淡路島市 $)$ \\
\hline
\end{tabular}


図 10 通天閣屋上階での時刻歴加速度波形の比較

図 11 通天閣地下階での時刻歴加速度波形 
続波では 1 次固有周期の卓越した波形が続いている．また，屋上階の最大加速度は NS 方向 $41.5 \mathrm{~cm} / \mathrm{s}^{2}$, EW 方向 $32.9 \mathrm{~cm} / \mathrm{s}^{2}$, 地下階の最大加速度が $\mathrm{NS}$ 方向 $13.0 \mathrm{~cm} / \mathrm{s}^{2}, \mathrm{EW}$ 方向 $9.3 \mathrm{~cm} / \mathrm{s}^{2}$ であり, 各方向で約 3.2 〜3.5 倍の最大加速度值の増幅が確認できる.

\section{2 シミュレーション解析結果}

シミュレーション解析では, 地下階での観測波形を振動モデルの最下端に入力した. 減衰は, 人力加 振実験から得られた減衰定数をもとに, 両方向ともレーリー型で 1 次, 2 次ともに $0.8 \%$ とた。解析に より求めた屋上階での加速度波形を, 観測波と比較して図 10 に示寸. 解析結果は観測結果の波形と概釈 良い対応であるが，最大加速度值が NS 方向，EW 方向それぞれ $35.9 \mathrm{~cm} / \mathrm{s}^{2}, \quad 26.1 \mathrm{~cm} / \mathrm{s}^{2}$ となり観測波に比 べやや小さく, NS 方向の 70 秒以降の後続波で振幅が小さくなっている. また，それぞれの波形の加速 度応答スペクトル（減衰定数 5\%）の比較を, 図 12 に示す. 図中には微動計測時の固有周期も併記する.

これより，両方向ともに，1 次と 2 次の各モードでの解析結果と観測結果の対応は良いが， 3 次モードで
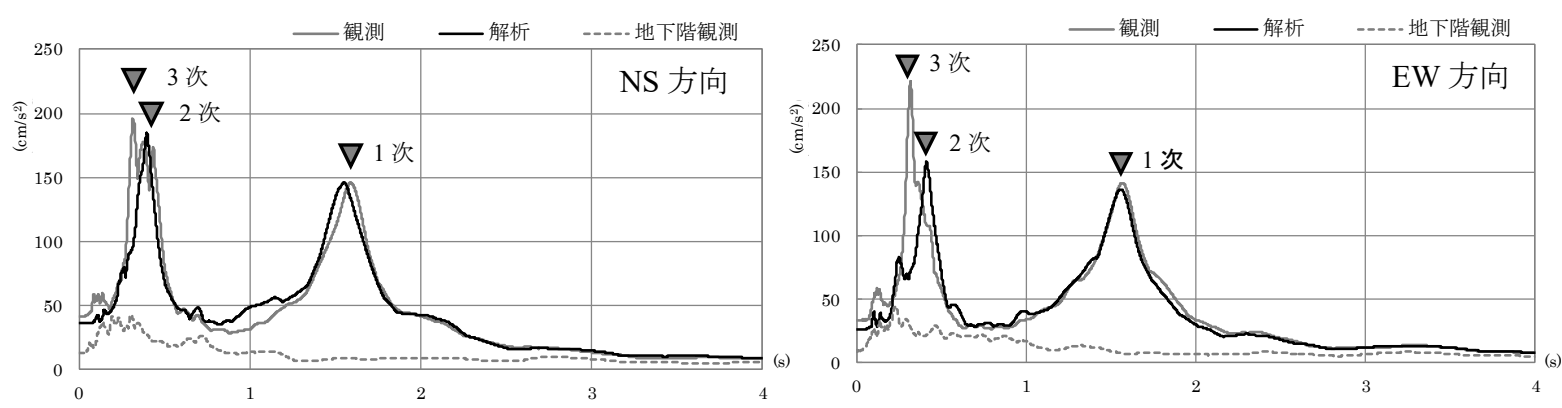

図 12 通天閣屋上階での加速度応答スペクトルの比較
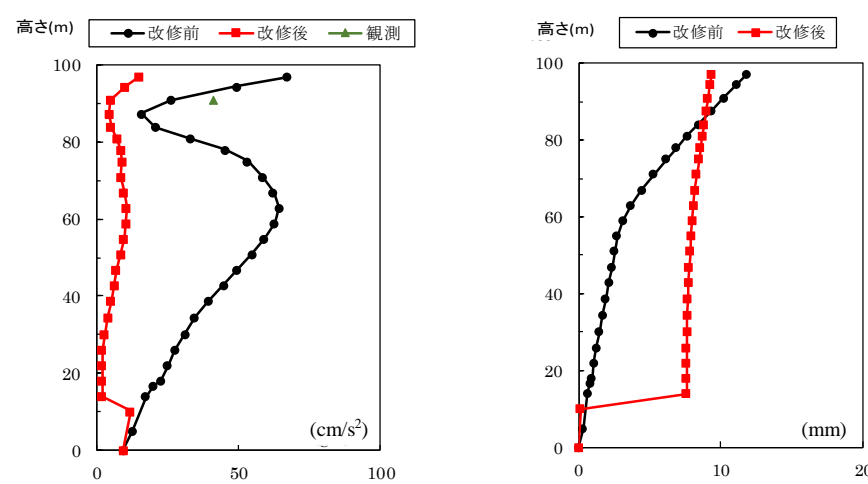

(a) NS 方向絶対加速度
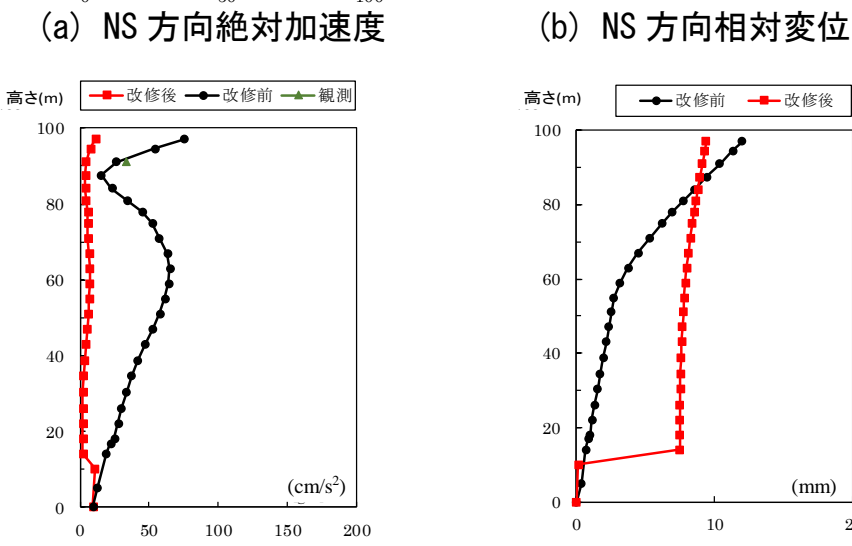

(c) EW 方向絶対加速度

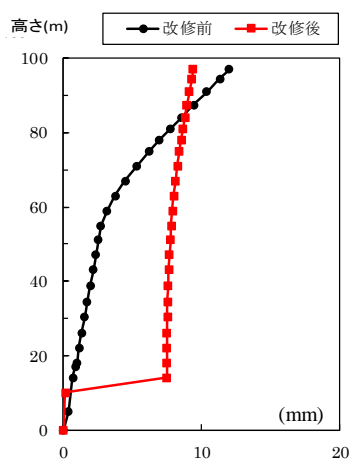

(d) EW 方向相対変位

図 13 改修前後のモデルを用いた最大応答值分布の比較 (2013 年淡路島の地震) 
は解析結果は観測結果より小さい。この理由として, 1 次と 2 次それぞれに $0.8 \%$ 減衰をレーリー型で 与えた場合に 3 次の減衰は $1.1 \%$ 程度となり ${ }^{11)}$ ，やや大きめの減衰を与えていることが考えられる.

図 13 に, 改修前後の解析モデルを用いて求めた絶対加速度と相対変位の最大值分布を比較して示寸. また，図中には屋上階での観測記録の最大加速度值も併せて示す.なお，改修後のモデルは後述の 7.2 に 示すモデルを用いている. 最大加速度分布は, NS 方向, EW 方向ともに改修前は 2 次, 改修後は 3 次の モードに近い形状となっている，また，改修後モデルとの比較から，搭全体の最大加速度と層間変形が 改修前に比べて大幅に低減し，改修による応答低減効果が期待できることが確認できる.

\section{2018年大阪府北部の地震のシミュレーション解析（改修後）}

図 7(b)に示した多質点曲げせん断型モデルを用いて, 改修後の観測地震のシミュレーション解析を行 った結果を以下に示す.

\section{1 観測地震と地震記録}

2018 年 6 月 18 日 7 時 58 分頃, 大阪府北部を震源とするマグニチュード 6.1 , 震源深さ $13 \mathrm{~km}$ の地震 が発生した。 地震のタイプは，逆断層型の内陸地殼内地震で，最大震度は 6 弱（大阪府高槻市）であっ た．地震の概要を表 6 に示す ${ }^{12}$. この地震では, 震源地にごく近い高槻市や茨木市で住家の被害が多数 発生したが，震度 6 弱の地域で確認できている約 60 棟の免震建物には被害はほとんどなかった ${ }^{13)}$.

通天閣の建設位置付近（大阪市浪速区）の震度は 4 であり，通天閣の屋上階と地下階に設置した地震 計（図 1 参照）で，図 14 と図 15 に示寸加速度波形が観測された。屋上階の波形を見ると，時間軸で 20 秒付近に短周期成分の振幅の大きい波形が目立ち，振幅の小さい後続波が続いている．屋上階の最大加 速度が NS 方向 $127.6 \mathrm{~cm} / \mathrm{s}^{2}$, EW 方向 $100.6 \mathrm{~cm} / \mathrm{s}^{2}$, 地下階の最大加速度が NS 方向 $178.3 \mathrm{~cm} / \mathrm{s}^{2}$, EW 方向 $116.1 \mathrm{~cm} / \mathrm{s}^{2}$ であり, 屋上階の最大加速度は地下階に比心゙約 $72 \% \sim 87 \%$ 程度に抑えられている. 地震後の聞 き取り調查から, 通天閣の構造体には被害はなく, 展望階では什器の移動もなく, おみやげ用の商品が 幾つか棚から落下した程度であった。また，エレベーターは一時停止したが間もなく復旧した ${ }^{13)}$.

表 6 観測地震の概要 ${ }^{12)}$

\begin{tabular}{|c|c|}
\hline 発生日時 & 2018 年 6 月 18 日午前 7 時 58 分頃 \\
\hline 震央 & 大阪府北部（北緯 34.8 度，東経 135.6 度） \\
\hline 震源深さ & 約 $13 \mathrm{~km}$ \\
\hline マグニチュード & 6.1 \\
\hline 最大震度 & $\begin{array}{c}6 \text { 弱（大阪市北区, 高槻市, 茨木市, } \\
\text { 箕面市, 枚方市) }\end{array}$ \\
\hline
\end{tabular}
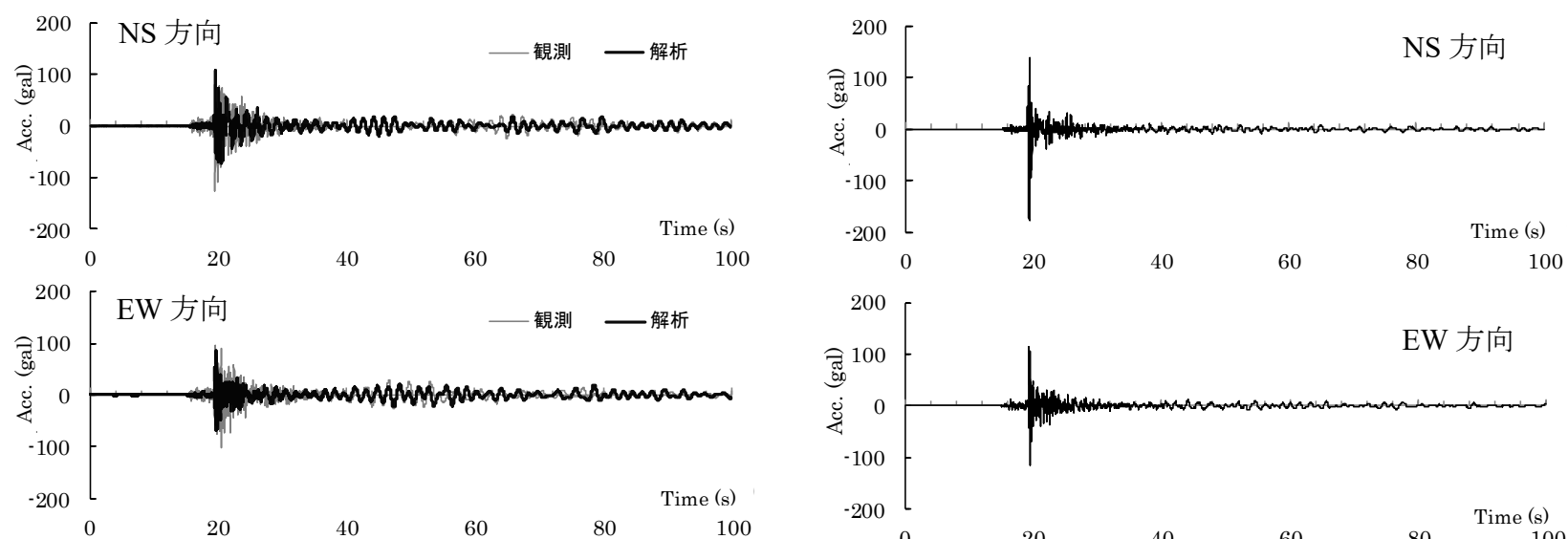

図 14 通天閣屋上階での時刻歴加速度波形の比較

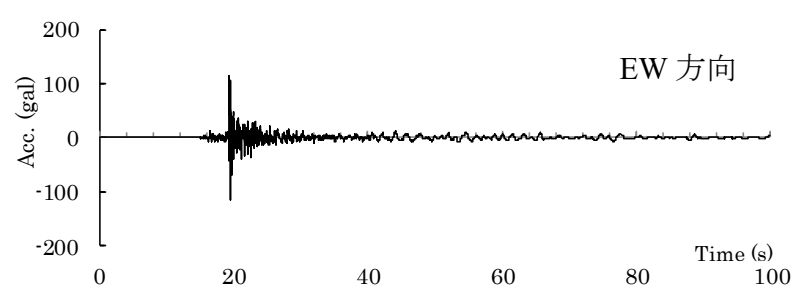

図 15 通天閣地下階での時刻歴加速度波形 


\section{2 シミュレーション解析結果}

シミュレーション解析では，地下階での観測波形を振動モデルの最下端に入力した．主塔の減衰定数 は, 改修前後で上部構造の変化がないため, 前述と同じ両方向ともレーリー型で 1 次, 2 次に $0.8 \%$ 与 えた. なお，改修後に行った常時微動計測結果から主塔の 1 次固有周期が 1.67 秒と確認できたため，上 部構造の剛性を調整した。積層ゴムの剛性に関しては, 表 3 に示した設計解析に用いた剛性を用いたケ 一スと, 本地震時の変形量を考慮して剛性を 2 倍したケースについても解析を行った.

解析により求めた屋上階での加速度波形（積層ゴムの剛性を 2 倍にした場合）を，観測波と比較して 図 14 に示寸. 解析では最大加速度が NS 方向, EW 方向それぞれ $108.7 \mathrm{~cm} / \mathrm{s}^{2}, \quad 85.5 \mathrm{~cm} / \mathrm{s}^{2}$ であり, 波形の 形状も含観測結果とほぼ対応している．積層ゴムの 2 つ岡性を用いたケースの屋上階の加速度応答 スペクトル（減衰定数 5\%）を，観測結果と比較して図 16 に示寸. 同図に示した地下階の観測記録から わかるように，本地震では 0.5 秒以下の高次成分が卓越する入力地震動であったために，NS 方向， EW 方向の観測結果に明瞭な 1 次ピークは確認できないが，NS 方向では 2.7 秒付近に，EW 方向では 3.5 秒
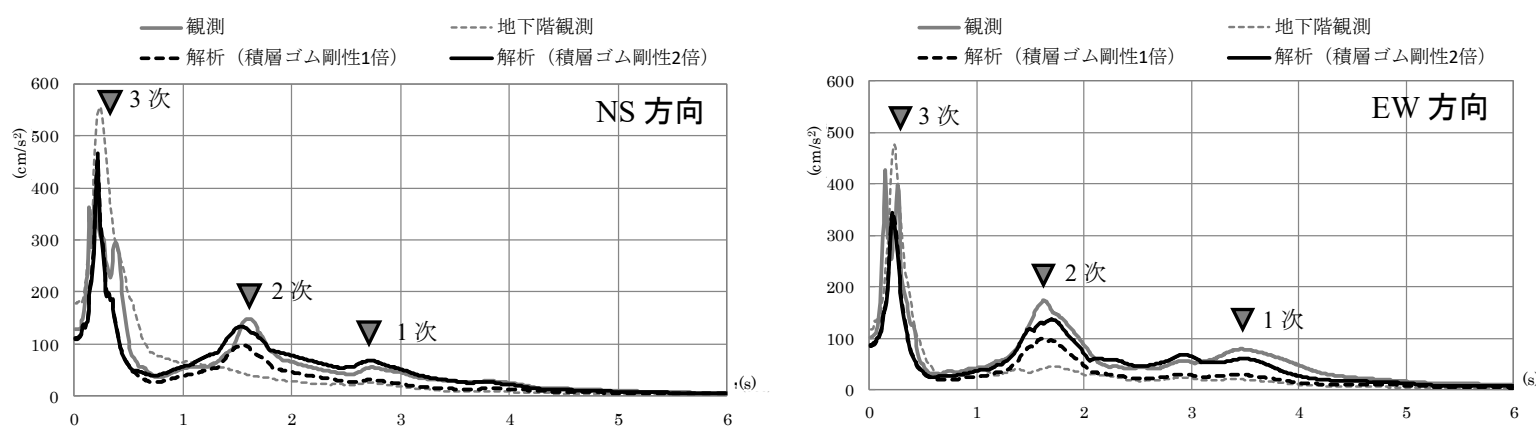

図 16 通天閣屋上階での加速度応答スペクトルの比較

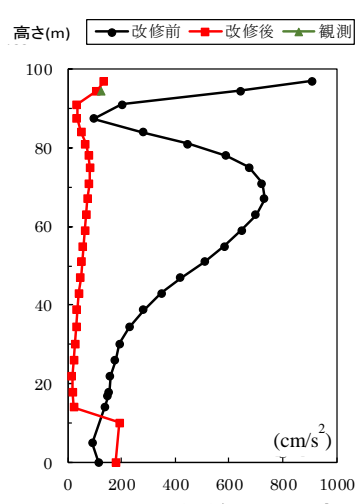

(a) NS 方向絶対加速度

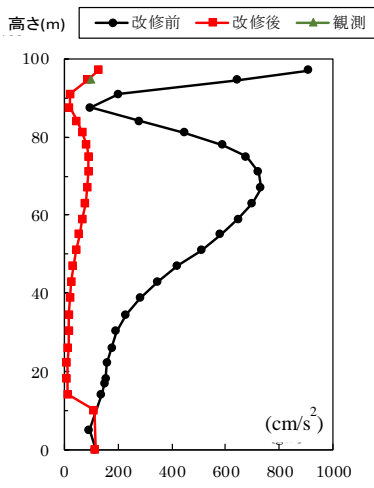

(c) EW 方向絶対加速度

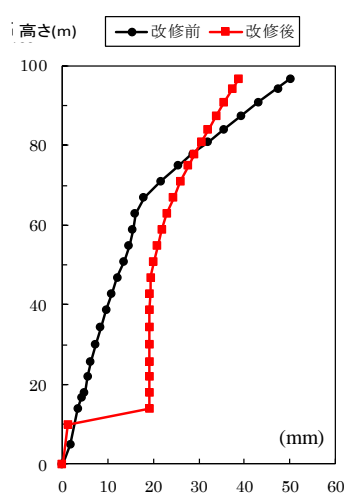

(b) NS 方向相対変位

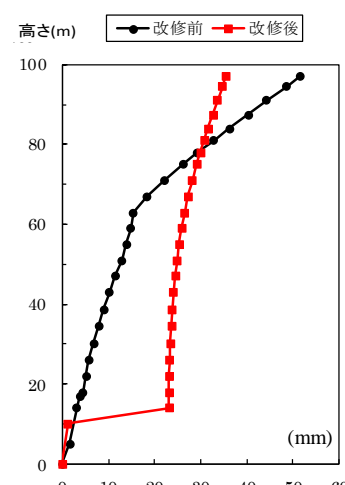

(d) $\stackrel{10}{E}^{10}{ }^{20}$ 方向相対変位

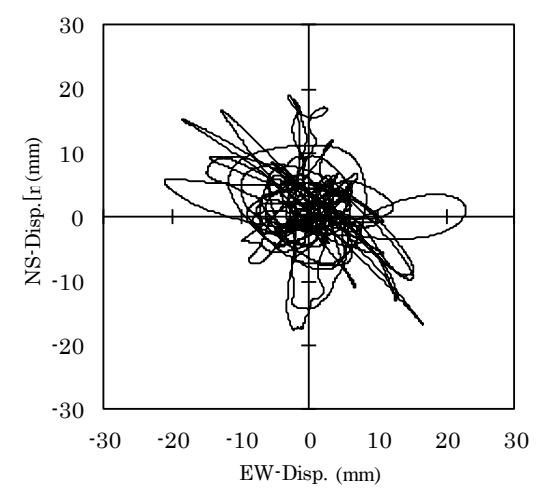

図 18 免震層の相対変位

図 17 改修前後のモデルを用いた最大応答值分布の比較 （2018 年大阪府北部の地震） 
付近に，振幅は小さいがピークが見られる．一方，各方向とも 2 次， 3 次のピークがそれぞれ確認でき る. 解析結果との比較では, 積層ゴムの剛性に設計用の值を用いたケースに比べ, 積層ゴムの剛性を 2 倍としたケースで観測結果と良く対応寸る結果となった.これは, 後述するように免震層の変形が $20 \mathrm{~mm}$ 程度と小さいため, 積層ゴムの小変形時の初期剛性が応答に影響を与えたことが考えられる．また，解 析結果は各次モードにおいて観測結果の応答性状と良く対応している.

図 17 に, 改修前後のモデルを用いて求めた絶対加速度と相対変位の最大值分布の比較を示す。また, 図中には屋上階での観測記録の最大加速度值を併せて示寸. 図 17(a), (c)の最大加速度分布より, 屋上階 の観測結果と解析結果は概ね一致している. さらに, 入力地震動の特性から改修前の最大加速度分布で は 3 次モードが卓越した形状となり, 中層部や上層部で $1000 \mathrm{~cm} / \mathrm{s}^{2}$ を超えている. 一方, 改修後では, 最 大加速度值は $200 \mathrm{~cm} / \mathrm{s}^{2}$ 以下となり，低減効果が大きいことが確認できる。図 17(b), (d)の最大相対変位 分布の比較より, 改修後は免震層で相対変位は $20 \mathrm{~mm}$ 程度となるものの, 免震層上部の層間変位の低減 効果が大きい. 図 18 に, 免震層上下間の相対変位の軌跡を示す. EW 方向の変形がやや卓越する挙動と なり, NS 方向, EW 方向ともに両振幅で最大約 $40 \mathrm{~mm}$ 程度と小さい変位であったことが確認できる. な お，免震層の片振幅の最大変位から最大ひずみを算出すると，約 $12 \%$ となった.

以上より, 大阪府北部の地震での通天閣の入力地震動は短周期成分が卓越した地震動であったため, 免震層の変形は小さかったが, 改修前では高次モードで応答が増幅したであろう主塔の加速度と層間変 位が，ともに免震効果により大きく低減したことを確認した。

\section{8. まとめ}

2015 年に免震改修を行った大阪通天閣の振動特性について検討するため, 改修前後の地震観測結果の シミュレーション解析を行った．以下に本研究で得られた結果をまとめる.

1) 免震改修前の微動計測結果から, 通天閣の 1 次固有周期は NS 方向, EW 方向ともに 1.56 秒, 1 次減 衰定数は $0.8 \%$ 程度であることがわかった。これらの值は, 建設直後の 1956 年に行われた計測結果と ほぼ同じ值であり，経年による振動特性の変化はほとんど無いことを確認した。

2) 免震改修前の 2013 年 4 月 13 日に発生した淡路島の地震のシミュレーション解析では, 振動計測結果 をもとに設定した地震応答解析モデルを用いて行い，屋上階での観測波形と良く対応寸る結果であっ た. 一方で, 高次モード, 特に 3 次モードの応答性状で解析結果は観測結果より小さい結果であった.

一因として，高次モードにおける減衰定数の与え方が影響していると考えられる.

3） 2015 年に行われた免震改修では, 4 本の脚部の免震層に天然ゴム系積層ゴムとオイルダンパーを設置 した構造となった．改修後に観測された 2018 年 6 月 18 日に発生した大阪府北部の地震のシミュレー ション解析では, 短周期成分が卓越した入力地震動であったことで免震層の変形が約 $20 \mathrm{~mm}$ と小さか ったために, 積層ゴムの剛性を設計解析時の 2 倍にすることにより観測結果と良く対応した．また, 改修前後のモデルを用いて応答性状を比較した結果, 高次モードでの応答低減に大きな効果を発揮し たことを確認した.

\section{謝辞}

本研究では, 通天閣観光 (株) 西上雅章会長, 高井隆光社長をはじめ関係各位の皆様のご協力により, 微動計測や地震計の設置を進めることができました。心より感謝の意を申し上げます．また，（株）竹 中工務店大阪本店設計部の関係者の皆様や, 大阪大学宮本研究室卒業生の横溝礼子様, 北浦杏菜様をは じめ研究室のメンバーの協力を得ました。ここに厚く御礼申し上げます.

\section{参考文献}

1) 通天閣観光株式会社 : 通天閣 50 年の歩み, 2007.

2) 地震調查研究推進本部地震調查委員会 : http://www.jishin.go.jp/main/index.html（参照 2019-05-01）

3) 宮本裕司，北浦杏菜，田中紳太郎，松原由典，山田晃平，西崎隆氏，日下 哲，鬼丸貞友：大阪通 天閣の免震レトロフィット（その 1) 〜 (その 4)，２015 年度日本建築学会大会学術講演梗概集 （関東），構造系 B-2, pp.667-674，2015. 
4）松原由典：建築画報（第 364 号），（株）建築画報社，pp.86-87，pp.92-93， 2015.

5) 内藤多仲，小川 正，田中弥寿雄 : 大阪通天閣の再建について，日本建築学会建築雑誌（12 月 号) , pp.39-43, 1956.

6) 那須信治, 竹内盛雄, 風間 了: 大阪通天閣の第 2 回振動実験, 1970 年度日本建築学会大会学術講 演梗概集（関東），構造系，pp.411-412，1970.

7) 奥村組 : 通天閣耐震診断報告書, 2010 .

8）横溝礼子，山口陽司，宮本裕司，瀧野敦夫，柏 尚稔：大阪通天閣の常時微動計測と風観測による 振動特性，日本建築学会近畿支部研究報告集，構造系 52 号, pp.37-40, 2012.

9) 北浦杏菜, 宮本裕司, 柏 尚稔: 大阪通天閣の振動特性と 2013 年淡路島の地震のシミュレーション 解析，日本建築学会近畿支部研究報告集，構造系 54 号, pp.189-190, 2014.

10）気象庁：2013 年 4 月地震・火山月報（防災編） http://www.data.jma.go.jp/svd/eqev/data/gaikyo/monthly/201304/monthly201304.pdf（参照 2019-05-13）

11）柴田明徳：最新而震構造解析（第 3 版），森北出版（株）, pp.68-69, 2014.

12）気象庁：2018 年 6 月地震・ 火山月報（防災編） http://www.data.jma.go.jp/svd/eqev/data/gaikyo/monthly/201304/monthly201304.pdf（参照 2015-05-13）

13）宮本裕司：2018 年 6 月 18 日大阪北部地震での免震建物調査, 日本免震構造協会会誌 $\lceil$ MENSHIN」, pp.30-36, 2018.

\title{
Simulation Analysis of Response of Seismic Isolated Tsutenkaku Tower during the 2018 Osaka North Earthquake
}

\author{
MIYAMOTO Yuji ${ }^{1)}$ and SATO Ayaka ${ }^{2)}$ \\ 1) Member, Professor, Graduate School of Eng., Osaka Univ., Dr.Eng \\ 2) Graduated Student, Graduate School of Eng., Osaka Univ.
}

\begin{abstract}
Seismic isolation retrofitting was conducted for Tsutenkaku tower of Osaka in 2015. The seismic isolation devices were installed at a height of about $9.5 \mathrm{~m}$ above the ground. In this study, microtremor measurement and earthquake observation were carried out to investigate the earthquake response characteristic before and after the seismic isolation retrofit. The 2013 Awaji Earthquake and the 2018 Osaka North Earthquake were observed at both the basement and the roof floor. Simulation analyses of these earthquakes were made to discuss responses by the effect of seismic isolation retrofit.
\end{abstract}

Keywords: Steel tower, Seismic isolation retrofit, Vibration measurement, Earthquake observation,

Simulation analysis 